\title{
ADMINISTRATIVE LIABILITY FOR VIOLATIONS OF ELECTORAL LEGISLATION AND ITS FEATURES
}

\author{
Turgunov Oybek Karimovich \\ Head of the Chair of the Military-Technical Institute of the National Guard of the Republic of \\ Uzbekistan, PhD in Law, Associate Professor
}

Article DOI: https://doi.org/10.36713/epra4070

\begin{abstract}
The article covers the actual legal responsibility and consideration of the courts for violations of the legislation during the elections to the representative bodies of state power of the Republic of Uzbekistan or limitation of citizens'voting rights in one way or another as well.
\end{abstract}

KEY WORDS: Elections, election commissions, voters, legal responsibility, administrative responsibility, courts.

\section{INTRODUCTION}

In the process of building a democratic legal state and modernizing the legal system of the state, radical reforms are carried out in the administrative law (responsibility), as with most basic legal branches. This branch of law is of paramount importance in maintaining the balance of public interest, in the organization and implementation of public administration, and in protecting the rights and legitimate interests of individuals and legal entities.

Administrative responsibility is a special type of legal responsibility and it has all the features. Administrative liability is established in accordance with legal norms, is applied for offenses committed by an individual and is expressed in the procedural sanctions imposed by the competent state bodies (officials).

\section{METHODS}

In addition to common administrative responsibilities, there are the following features:

Firstly, administrative responsibility is established both by laws and by-laws, that is, it has its own legal and regulatory framework;

secondly, the basis of administrative responsibility is administrative offense (in the case of violations of the law and misconduct); thirdly, citizens and officials appear as subjects of administrative responsibility;

Fourth, administrative penalties are imposed for administrative offenses;

fifth, administrative responsibility is applied by a wide range of state bodies (officials) in accordance with the legislation.

Administrative liability generally arises when the requirements of administrative law are violated. But at the same time, the current legislation shows that administrative responsibility can be applied to violations of constitutional, labor, financial, land and other legal norms. This, in turn, indicates the intersectoral importance of administrative responsibility.

\section{RESULTS AND DISCUSSIONS}

Article 1 of the Code of Administrative Responsibility of the Republic of Uzbekistan, adopted on September 22, 1994 and entered into force on April 1,1995 [1], establishes the legal basis of administrative responsibility according to which the legislation on administrative responsibility, Laws of the Republic of Uzbekistan, resolutions of the Oliy Majlis of the Republic of Uzbekistan, decrees of the President of the Republic of Uzbekistan, resolutions of the Cabinet of Ministers of the Republic of Karakalpakstan laws of the Republic of Karakalpakstan, decisions of the Jokargy Kenes of the Republic of Karakalpakstan and Council 


\section{EPRA International Journal of Research and Development (IJRD) \\ Volume: 5 | Issue: 2 | February 2020 \\ - Peer Reviewed Journal}

of Ministers, decisions of provincial and Tashkent city councils of people's deputies, governors of provinces and Tashkent city.

The legislation on administrative responsibility enforces the rights and freedoms of citizens, the protection of property, state and public order, the environment, social justice and legality, the timely and objective consideration of administrative offenses, as well as the prevention of such violations; to educate citizens in the spirit of adherence to the Constitution and laws of the Republic of Uzbekistan.

The legislation on administrative responsibility is based on the principles of legality, equality of citizens before the law, democracy, humanism, justice and inevitability of responsibility for guilt. As with any legal liability, the factual basis of administrative responsibility is a violation. According to Article 10 of the Code of the Republic of Uzbekistan on administrative responsibility, an administrative offense is illegal, intentional or careless (aggression or negligence) encroaching on the person, citizens' rights and freedoms, property, state and public order, natural environment, which are subject to administrative liability) is an action or inaction.

In accordance with the Law of the Republic of Uzbekistan "On Introduction of Amendments and Addenda to Some Legislative Acts of the Republic of Uzbekistan" dated September 4, 2014 [2], the Administrative Code of the Republic of Uzbekistan was first introduced filled with chapters. This chapter provides eight articles (Articles 51.2 - 51.9) that provide for administrative liability for possible electoral violations. In this case, the law clearly states to whom and where to apply in case of violation of rights and legitimate interests of participants and subjects of the electoral process.

The current legislation guarantees the right to appeal to a higher election commission or court, as a rule, on decisions and actions of election commissions. It is noteworthy that guarantees of all rights and interests of our citizens cannot be imagined without judicial independence. In this context, as President Shavkat Mirziyoev said in his address to the $27^{\text {th }}$ anniversary of the adoption of the Constitution, "Ensuring genuine independence of the courts is our highest priority.

In particular, the court must not allow any official to become an agency that can be used by anyone. Therefore, it is necessary to strengthen the responsibility for interfering in the court proceedings or pressure on the court"[3].

In his appeal to the Oliy Majlis, President of the Republic of Uzbekistan Shavkat Mirziyoyev said: "Let government officials understand this: the issue of judicial independence will remain under the personal control of the President. Every step of the court should make sure that justice is prevailing in Uzbekistan. Otherwise, as the great German philosopher Immanuel Kant puts it, "when justice is lost, there will be nothing left to determine the value of life". We must never forget this fact. Judges in Uzbekistan should be strong advocates of the law and strong pillars of justice"[4].

Indeed, courts and judges must be fully independent in their activities, and only obey the law and take fair, well-grounded and lawful decisions. Only then will people's trust in the judiciary and the judiciary increase, while the worst vices, elements, and misery in society will be eliminated, and our society will grow on the principles of justice.

In our society, all matters, in particular, may apply directly to the courts without having to appeal to a higher election commission over the concerns of election commissions. However, failure to submit a complaint to a higher election commission does not preclude the right of the interested party to apply to the court.

In accordance with the current Election Code, joint sessions on the election of members of the Jokargy Kenes of Karakalpakstan, local Councils of relevant provinces, Tashkent city, as well as districts and cities, as well as decisions of the Central Election Commission of the Republic of Uzbekistan the Court of Appeal. Because they are the highest instances, there is no higher election commission that can assess the legitimacy of their decisions.

Bodies of political parties nominating candidates for deputy, candidate candidates, proxies, observers and voters may appeal decisions of election commissions to a higher election commission or court within ten days after such decision has been taken. Appeals against decisions of election commissions are usually filed with the administrative courts at the place of responsibility. Joint meetings and decisions of the Central Election Commission shall be appealed to the Supreme Court of the Republic of Uzbekistan within ten days after the decision. Of course, the current legislation clearly sets out the procedure and timing for the consideration of such complaints by the courts. That is, courts consider these complaints within three days of receipt of the complaint, and at least six days before the election. For example, if a voter fails to review or unreasonably refuse to submit a request for correcting an error or inaccuracy in the voter list within 24 hours, preventing the right to early voting or using the right to vote, to apply to the court for non-consideration or refusal.

Considering the requirements of the applicable law, article 51-4 of the Code of Administrative Offenses violates the rights of a candidate, trustee, 


\section{EPRA International Journal of Research and Development (IJRD)}

Volume: 5 | Issue: 2 | February 2020

- Peer Reviewed Journal

observer or an authorized representative of a political party - that imposes a fine on officials of five to ten times the minimum wage. Here is another point. In other words, in the election process, there are cases of spreading false information in order to discredit candidates or political parties. Our legislation also provides liability for this type of offense. For example, Article 51-6 of the Code of Administrative Responsibility establishes the responsibility for this type of offense. According to him, deliberately publishing or otherwise spreading false information about a candidate or political party in order to influence the election results will result in a fine of three to five times the minimum wage for officials and five to ten times the minimum wage for officials. The case on administrative offenses is considered by administrative courts within one day from the date of receipt of the report on administrative offenses and other case materials.

Disputes concerning actions and decisions of election commissions shall be considered by district (city) administrative courts in accordance with Article 27 of the Code of Administrative Procedure. Also, in accordance with Article 30 of this Code, the Supreme Court of the Republic of Uzbekistan considers cases of dispute on the actions or decisions of the Central Election Commission of the Republic of Uzbekistan. Complaints against decisions of the election commission shall be considered in the presence of the applicant, representative of the relevant election commission, prosecutor, and inviting that person if the complaint concerns another citizen, not the applicant. Failure of these persons to appear shall not impede the hearing of the case.

As for the consequences of invalidating the election results, if a complaint against the decisions of the election commission is satisfied, the court's decision is immediately passed to the relevant election commission and the applicant. The Electoral Code also states that elections in general or in certain constituencies or in certain polling stations may be invalidated due to violations committed during the election, which have affected the voting results.

The Central Electoral Commission shall decide on the invalidation of the elections to the Legislative Chamber. The decision can be appealed to the Supreme Court of the Republic of Uzbekistan within ten days after the announcement of the election results. It is well known that the decision to declare elections to local councils invalid shall be made by the relevant election commission. This decision can be appealed in court within ten days from the announcement of the voting results.
The decision of the court shall be immediately delivered to the relevant election commission and the applicant. A party that is dissatisfied with the decision of this court may file a complaint to the higher court, and the prosecutor may file an appeal. The current law also provides for appropriate interference in the electoral process. For example, Article 51-2 of the Code of Administrative Responsibility imposes a fine of ten to fifteen times the minimum wage on officials for interfering in the activities of the Central Election Commission of the Republic of Uzbekistan, election commissions, referendum commissions, as well as for obstructing their work cause. Also, article 51-3 of this Code provides for a fine of three to seven times the minimum monthly wage for non-executing decisions of the Central Election Commission, election commissions, for refusing to consider their appeals or for violating the terms of their consideration without valid reasons. is inserted.

In addition, a candidate, proxy, observer or an authorized representative of a political party may apply to the relevant election commission, the law enforcement agencies and the prosecutor's office if they believe their rights are being violated. In the event that the rights of the aforementioned persons are found to be violated, officials shall be punished by a fine of five to ten times the minimum wage as defined in Article 51-4 of the Administrative Code.

The law also provides for liability for violations of election financing procedures. In particular, Article 51-8 of the Code of Administrative Responsibility imposes penalties of five to ten times the minimum wage for officials and ten to twenty times the minimum wage for violations of election financing procedures. The publication or publication of documents on election results without their approval by the relevant election commissions also entails liability. Violation of public opinion polls, election results, as well as other electionrelated surveys and announcements in accordance with Article 51-9 of the Code on Administrative Responsibility shall be punished with a fine from five to twenty times.

Cases of administrative offenses committed during the election process are registered by the prosecutor's office and law enforcement agencies. Within 24 hours of receiving notification to the police or prosecutor's office, the actions of the alleged perpetrator will be investigated at the crime scene with the participation of election commission members and, where appropriate, the reporting person.

Subsequently, the documents collected in the course of investigations are made within one day from the moment of committing or detecting violations, in accordance with Article 282 of the Code of 
Administrative Offenses, along with a report on administrative offenses or other facts and physical evidence on the case. go to the district (city) administrative court for consideration of cases.

Expert $\mathrm{Yu}$. Chokan it is advisable to quote that in his view, an open and transparent election is a key factor in a realistic assessment of the electoral process. These principles, in turn, prevent violations of electoral legislation. There is an important legal basis to ensure that there are no violations of electoral legislation in the forthcoming elections in Uzbekistan. This is, of course, the Electoral Code. The norms contained in this Code comply with international standards for fair and fair elections. That is why the Electoral Code of Uzbekistan has been widely assessed internationally [5].

\section{CONCLUSION}

In short, from the peculiarities of accountability for violations of electoral legislation, we can conclude that Uzbekistan has accumulated sufficient experience in the further development of parliamentarism and the democratic and transparent electoral process.

\section{REFERENCES}

1. Bulletin of the Supreme Council of the Republic of Uzbekistan, 1995.-№3. (with subsequent amendments) (In Uzbek)

2. Collection of Laws of the Republic of Uzbekistan, 2014.-№36. (In Uzbek)

3. Statement by President Shavkat Mirziyoev at the solemn ceremony dedicated to the 27th anniversary of the Constitution of the Republic of Uzbekistan December 07, 2019.

4. Appeal from the President of the Republic of Uzbekistan Shavkat Mirziyoev to the Oliy Majlis 24.01.2020 (In Uzbek)

5. Yurie Chokan is a professor at the Moldovan State University and a former member of the Central Election Commission of the Republic of Moldova. 